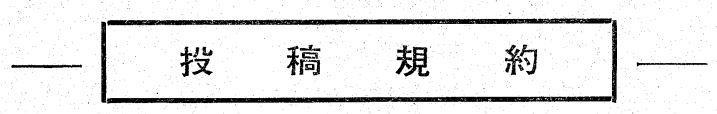

I 、原稿ば次の規定により寄稿して下さん

（1）未發表のもので本會所定の原稿用紙（400 字詰）または市販の原稿用紙（400 字詰)にひらがを交り（をるべく新かをづかい制限漢字によるも，術語はその 限りで恋い）橫書で圖版，表を含夕 1 回 27 枚以內でカーブとテーブルがダブ らなんようと書く。

（2）邦交の寄稿には 200 語程度の英文又は獨文のアプストラクトを必ずつける.又 表おさざ圖の說明は出來だけ英文又は獨文とする。

（3）數字はすべてアラビヤ數字を使用する，ただし慣用されてんるものはなまわな h.

（4）數式および一般記號を邦交の行內に記入するときは，なるべく b/a，(a+b)/ (c+d)のように記し，行の下に出さをんようにする。

（5）カーブ等印刷に版走要するものは直ちに縮寫, 製版できるよう原圖は白紙に 明瞭飞墨書する。

（6）抄錄譯文および文献の出所は著者名, 雜誌名, 然, 號, 頁數, 發行年度の順に 記載する。

\title{
黑鉛化に關する研究（第2 報）
}

圭として黑鉛化による結晶構造の變化に就へて

昭和電工秼式會社大町工場 山口茂, 野口利 雄, 八田三郎

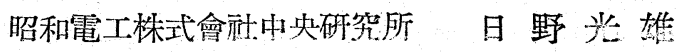

\section{Studies on Graphitisation II.}

Mainly on the structural change of carbonaous materials by graphitisation

By

Shigeru Yamaguchi, Toshio Noguchi, Saburō Hatta and Mitsuo Hino.

(The Showa Denkō 'Co., Ltd.)

In this paper, we investigated the structural change of carbonaous raw materials 
during graphitisation, by means of X-ray diffraction. Laue-Brill's equation was used for crystallite-size determination. Same specimens as in the proceeding paper were used.

Graphitisation is the continuous change from the Warren's "Random layer lattice structure" to the graphite-like lattice structure. In some specimens, two-dimentional $(\mathrm{hk}) \cdot$ band co-exist with broad three-dimentional (hk $l$ ) line.

Among 5 raw materials studied, petroleum coke is the most graphitisable, pitch coke is the next and acetylene black is the least.

\section{1. 緒 合}

第 1 報に知て我々は 3 種類の黑鉛化度测定方法 師方真比重测定，黑鉛酸定量，X線备折の間の相 關に就いて研究し，且比重值の报いて注意すれば 3 者は夫ぬ黑鉛化度の判定に用い得るこ己を示し 社.

本報には黑鉛化による炭素原料の結晶構造の變 化に就き，X線趈折による觀察を主として远べ る. 黑鉛化現象衣本質的には炭素の結晶構造の變 化でするから，X線呬折によつて結晶の狀態を觀 察する方法は，他之較心゙最も直接的后研究方法 で西る己考へら机る。我々は炭素及び黑鉛試料の X線呬折寫真力ら格于常數と結晶粒于の大きさと を测定し，黑鉛化に仯ふそれらの變化及び炭素原 料によ当黑鉛化の難易の程度を調べを。

\section{2. 試 翻}

試料の大牛は第 1 報記載の, グレートレーキ石 油コークス，ピッチコークス，木炭，無煙炭，ア セチレンブラックを原料とする黑鉛化試料である が，他に人造黑鉛と比較の目的の亦飞數種の黑鉛 試料它供試した。 それらは秋のものである。

（1）朝鮮産鱗片狀天然黑鉛

（2） $\mathrm{CaC}_{2}$ を $2300^{\circ} \mathrm{C}$ で分解させた黑鉛

(3) $\mathrm{Fe}_{3} \mathrm{C}$ を $2300^{\circ} \mathrm{C}$ で分解させを黑鉛

（4）カーボランダム製造爐より探取した SiC の分解黑鉛

天然黑鉛試料及び無煙炭を原料とする試料は多 くの灰分を含むから，事前に化學的に洗滌した。

\section{3. 測定方法}

\section{3-1 测定裝置}

結晶粒子の大きさは Laue-Brill の式12)3) を使 つて迴折線斗價幅から計算したので，X線寫畺撮 ・影裝置はをるべく Laue の指定する條件に合う樣 ひ心掛けた。

X線将 $\mathrm{Ni}$ 䈃で滤波した $\mathrm{CuK} \alpha$ 線を用ん，對
㓌極は上面が水本存るのを用いて本をいX線束が 試料澢る樣にする。カメラのスリットは圓孔を 穿つた鉛板一枚で，孔の徑を $0.1 \mathrm{~mm}$ から 0.5

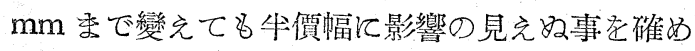
てから，0.3 $\mathrm{mm}$ のものを脚を。

使用しそフィルム梳 0.6 以下の黑化度がX線强 度之略直線的關係を保つものであつた。 そてでX 線舁真の露出をとの範園飞抑え, 手動のミクロフ オトメーターで强度分布制線をとつた。

\section{3-2. 格子常數の测定}

(00l) 線が撗がつている場合には層面間隔の測 定に Franklin の補正 ${ }^{4}$ 少必要である己思ほれる

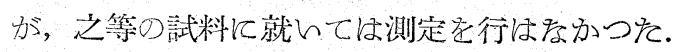
二次元格子趧折帶办ら蜂の巢面の原子間隅学求的 るに賞つては，Warren の補正5)を行つたが，無 秩序壓格子構造己三次元格子構造との中間の迴折 老與入る試料に就んての測定には何の補正も行は 学加灰。

\section{3-3. 結晶粒子の大きさの测定}

結晶粒子の大きさの計算には次式を用いた。

$$
\begin{aligned}
b^{\prime} \cos \theta-\frac{1}{b}(\pi r)^{2} \cos ^{3} \theta \\
=R \lambda\left\{\frac{\left(\frac{h}{l_{a} a}\right)^{2}+\left(\frac{h}{l_{b}^{b} b}\right)^{2}+\left(\frac{l}{l_{c} c}\right)}{\left(\frac{h}{a}\right)^{2}+\left(\frac{k}{b}\right)^{2}+\left(\frac{l}{c}\right)^{2}}\right\}^{\frac{1}{2}}
\end{aligned}
$$

此處て, $b^{\prime}$ :迴折線阧價幅, $\theta$ : 迴折筩, $r$ : 試料棒牛

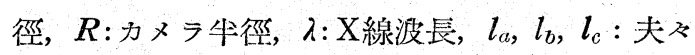
$a, b, c$ 軸方向えの結晶の大きさ，である。

物理學的に嚴密に云ふなら, 此の Laue-Brill の 式にも種々諭議の餘地がある筈であるが，一應之 を信用してし李万事にする。そ礼我及の值は絕 對值として正しんものではない. Scherrer6) の式 によつて計算した他の研究者たちの值と較へる 之，我々の值は過大に見える。 
（1）式から無限に發達した結晶の迴折線斗價幅 ほ

$$
b^{\prime}{ }_{\infty}=\pi r \cos \theta
$$

とをる。稀繹した食監試料のX線寫這に就んて實 際に测定すると， $\theta<45^{\circ}$ の範圍であれば牛價幅 は撖密に（2）式に一致した。供試しを天然黑鉛 の（110）線住就んても同樣でめる。

（1）式吕ら結晶の大きさを計算する場合の精

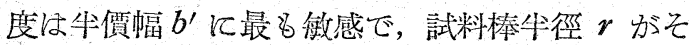
れに次ぐ. 多くの牛價幅の測定值からその母分散 を推定しそ處，太々本價幅のもの程分散の大きい 結果が出をが，例えば約 $1 \mathrm{~mm}$ の本價幅の標準 偏差約 $5 / 100 \mathrm{~mm}$ で西つを。（ $\boldsymbol{r}$ は約 $0.25 \mathrm{~mm}$, $R$ は約 $35 \mathrm{~mm}$ の場合) 試料棒牛征 $\boldsymbol{r}$ 《は $\pm 0.03 \mathrm{~m}$

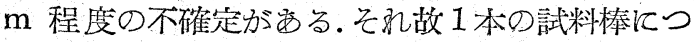
き2枚の寫眞を撮り.計 4 本の迴折線の牛價幅を測 定して本均值を己つを場合, 例えば (110) 線より の䚄面值徑の值には大凡 Fig.1 亿示しそ程度の不

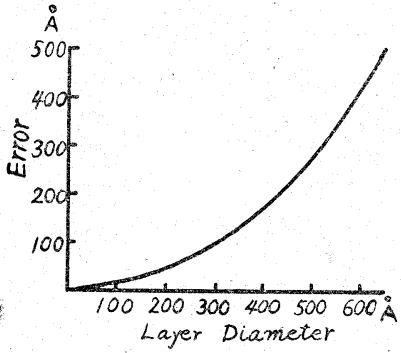
culated layer diameter
Fig. 1. Uncertainty of cal確定加避け難い。

Fig.1以層面值徑力 $500 \AA$ 工計算さ礼 そ場合飞，その前 後約 $300 \AA$ 範圍 の不確定がある己 云う意である。そ の信賴度は約 $70 \%$ である。勿論之は 迴折線强度分布吕左右對稱でする場合に就んての 話である。强度分布办機分己も二次元格子趣折帶 的な非對䊈守示するのに就んては檢討してない.

二次元格子趈丰帶よ $b$ の直徑測定には，理論的 基礎は不確かでするが Biastoch \& Hofmann の 方法7を用いた。 Warrenの式5は使はをい，之に は實驗上の趈折線の幅に對する補正項がをく，又

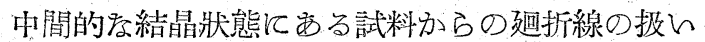
に困るのである。

\section{4. 測定結果}

\section{4-1. 黑鉛化に伴ふ X線圖の變化}

處理溫度を高省に從つて試料のX線寫真は上 く知られた變化を示す ${ }^{8)}$. そして $(\boldsymbol{h} k l)$ 線の出現 は，Warren の無秩序厤格子構造加ら黑鉛格子類 似の構造への進化を示するのであるが，我ふの試 料作製條件（昇溫速度約 $100^{\circ} \mathrm{C} /$ 分，最終溫度で
の保持約 3 分）の下でそれが明らかに現れるの は, G.L., P.C., Anth., では $2300^{\circ}$ C, C.C. では $2750^{\circ} \mathrm{C}$, A.B. では $3000^{\circ} \mathrm{C}$ でる。 そして $(h k l)$ 線の出現は連續的である樣に見える。C.C., A. B. を原料とする試料の系列では，简度の大きい方に 流れた (11) 帶の外側に，攄がつた (112) 線が 炊第飞强く現れ，(112) 線力現れた後にも（110) 線の分布の非對筝は明ら分江殘つてるる。逆格子 空間飞就んての考察から明らかで步るが，角度の 大堂的方への迴折隆起の流机に二次元格子小りの 闻折の場合ばかりでなく，c軸方向が $a, b$ 軸方

Table 1. $d$-values and specific gravities

\begin{tabular}{|c|c|c|c|c|c|}
\hline Specimen & $\stackrel{d(002)}{\AA}$ & $\stackrel{d(110)}{\AA}$ & $\begin{array}{c}\text { Specific } \\
\text { Gravity } \\
\text { from Lat- } \\
\text { tice const. }\end{array}$ & $\begin{array}{l}\text { Specific } \\
\text { Gravity } \\
\text { Mesured }\end{array}$ & $\begin{array}{l}\text { Cryp- } \\
\text { tic } \\
\text { Pore } \%\end{array}$ \\
\hline $\begin{array}{cc}\text { G.L. } & 1450^{\circ} \mathrm{C} \\
\text { " } & 1900 \\
\text { "I } & 2300 \\
\text { " } & 2750 \\
\text { " } & 3000 \\
\text { " } & 3200\end{array}$ & $\begin{array}{l}3.45 \\
3.43 \\
3.37 \\
3.36 \\
3.36 \\
3.35\end{array}$ & $\begin{array}{l}1.225 \\
1.225 \\
1.226 \\
1.228 \\
1.230 \\
1.228\end{array}$ & $\begin{array}{l}2.21 \\
2.22 \\
2.26 \\
2.26 \\
2.25 \\
2.26\end{array}$ & $\begin{array}{l}2.130 \\
2.162 \\
2.212 \\
2.229 \\
2.236 \\
2.231\end{array}$ & $\begin{array}{l}4 \\
3 \\
1 \\
0.5 \\
0.5 \\
1\end{array}$ \\
\hline $\begin{array}{cc}\text { P.C. } & 1450^{\circ} \mathrm{C} \\
\prime \prime & 1900 \\
\prime \prime & 2300 \\
\prime \prime & 2750 \\
\prime \prime & 3000 \\
" \prime & 3200\end{array}$ & $\begin{array}{l}3.44 \\
3.42 \\
3.37 \\
3.37 \\
3.37 \\
3.37\end{array}$ & $\begin{array}{l}\text { 1. } 22_{5}{ }^{*} \\
\text { 1. } 22_{5} \\
1.228 \\
1.228 \\
1.228 \\
1.228\end{array}$ & $\begin{array}{l}2.22 \\
2.22 \\
2.25 \\
2.25 \\
2.25 \\
2.25\end{array}$ & $\begin{array}{l}2.055 \\
2.067 \\
2.118 \\
2.137 \\
2.156 \\
2.186\end{array}$ & $\begin{array}{l}7 \\
7 \\
6 \\
4 \\
4 \\
2\end{array}$ \\
\hline $\begin{array}{c}\text { Anth. } 1450^{\circ} \mathrm{C} \\
\text { " } 1900 \\
" 1300 \\
" 12750 \\
\text { " } 3000 \\
\text { " } 3200\end{array}$ & $\begin{array}{l}3.44 \\
3.39 \\
3.38 \\
3.37 \\
3.37\end{array}$ & $\begin{array}{l}1.22_{0} \\
1.22_{5} \\
1.228 \\
1.230 \\
1.228 \\
1.228\end{array}$ & $\begin{array}{l}\overline{2.22} \\
2.24 \\
2.24 \\
2.25 \\
2.25\end{array}$ & $\begin{array}{l}1.764 \\
1.838 \\
1.987 \\
2.056 \\
2.089 \\
2.088\end{array}$ & $\begin{array}{r}\overline{17} \\
11 \\
8 \\
7 \\
7\end{array}$ \\
\hline $\begin{array}{cc}\text { C.C. } & 1450^{\circ} \mathrm{C} \\
\prime \prime & 1900 \\
\prime \prime & 2300 \\
\prime \prime & 2750 \\
\prime \prime & 3000 \\
\prime \prime & 3200 \\
\end{array}$ & $\begin{array}{l}-t+t \\
-t \\
3.45 \\
3.41 \\
3.38 \\
3.37 \\
-\end{array}$ & $\begin{array}{l}1.21_{5} \\
1.22_{5} \\
1.22_{0} \\
1.228 \\
1.230 \\
1.230\end{array}$ & $\begin{array}{l}\overline{-} \\
\overline{2.22} \\
2.22 \\
2.24 \\
2.24\end{array}$ & $\begin{array}{l}\text { 1. } 450 \\
1.472 \\
1.569 \\
1.824 \\
1.988 \\
1.973\end{array}$ & $\begin{array}{l}- \\
\overline{29} \\
18 \\
11 \\
12\end{array}$ \\
\hline $\begin{array}{cc}\text { A.B. } & 1450^{\circ} \mathrm{C} \\
\text { " } & 1900 \\
\text { " } & 2300 \\
\text { " } & 2750 \\
\text { " } & 3000 \\
\text { " } & 3200\end{array}$ & $\begin{array}{l}-\dagger \\
3.44 \\
3.43 \\
3.41 \\
3.40 \\
3.40\end{array}$ & $\begin{array}{l}\text { 1. } 22_{0}^{*} \\
1.22_{0} \\
1.22_{5} \\
1.225 \\
1.228 \\
1.228\end{array}$ & $\begin{array}{l}\overline{2.23} \\
2.22 \\
2.23 \\
2.23 \\
2.23\end{array}$ & $\begin{array}{l}1.952 \\
2.018 \\
2.053 \\
2.039 \\
2.046 \\
2.056\end{array}$ & $\begin{array}{l}- \\
9 \\
8 \\
9 \\
9 \\
8\end{array}$ \\
\hline $\begin{array}{l}\text { Natural Flake } \\
\text { Graphite }\end{array}$ & 3.35 & 1. 228 & 2.26 & 2.260 & 0 \\
\hline $\begin{array}{l}\text { Graphite } \\
\text { from } \mathrm{CaC}_{2}\end{array}$ & 3.35 & 1. 2.8 & 2. 26 & 2. 242 & 1 \\
\hline " $\mathrm{Fe}_{3} \mathrm{C}$ & 3. 36 & 1. 228 & 2.25 & 2.267 & 0 \\
\hline$\| \quad \mathrm{SiC}$ & 3.35 & 1. 228 & 2.26 & 2. 254 & 0 \\
\hline
\end{tabular}

* Exchanged from $d_{-10}$ value.

$\dagger$ Diffractions were too broad to calculate without correction. 
向に較ベて極めて薄い三次元格子よりの(hko) 趈 折の昜合にも起る筈である。

此の樣沅. 無秩序層格子構造少至鉛格子類似 の構造への變化ほ不連續でをく䭪，連續的なもの と考へられる。

\section{4-2. 格子常數己比重}

Table $1 飞 d_{(002)}, d_{(110),}$, 結晶の比重, ベンゾ 一ルを浸漬液として测定した。真比重, 隱蔽孔度 8)10）を揭げておく．Fig，2 は㲊面間隔の減少を 示与. G.L.,PC., Anth. では, $(h k l)$ 線の現れる $2300^{\circ} \mathrm{C}$ て $d_{(002)}$ の㮐急激な減少が見元る。極限 值の $3.35 \AA$ へ達するのは G.L. のみで西つた。 $d_{(110)}$ の黑鉛化に伴ふ增加注 $d_{(002)}$ の減少に較べ て僅かであり，その雹格子常數から計算した比重 は黑鉛化に從つて增加する傾向加焉る。

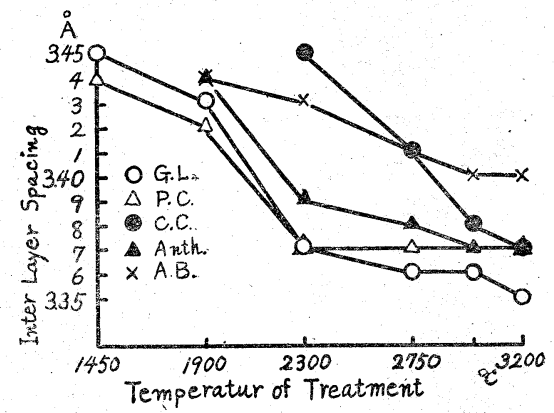

Fig. 2. Inter layer spacing

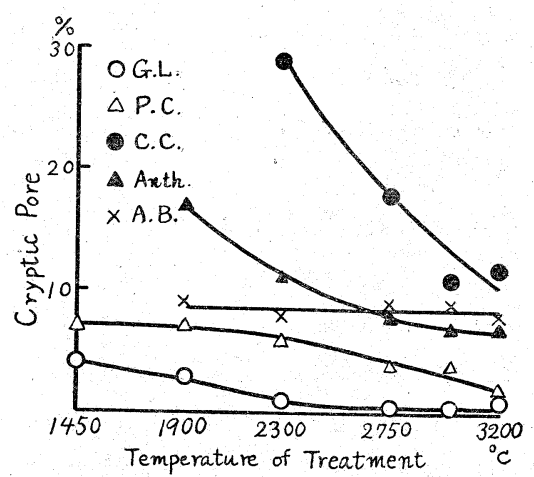

Fig. 3. Cryptic Pore

Fig. 3 には遮蔽孔度の減少を示した。遮蔽孔度 とは要するに，ピクノメーターによる橿比重测定 の場合飞侵漬液の達し得质い容積の割合でする。 高溫に加熱處理した G.L. では此のめくら孔が殆 ぞをん. A.B. の遮蔽孔度は加熱處理によつて殆 ぞ變らす。測定による真比重值の增加は，總へて 結晶の比重の增加によつてんるのである。
Table 2. Crystallite-Size in Angstrom

\begin{tabular}{|c|c|c|c|c|}
\hline \multirow{2}{*}{ Specimen } & \multicolumn{2}{|c|}{$\begin{array}{l}\text { Height of Parallel- } \\
\text { Layer Group }\end{array}$} & \multirow{2}{*}{\begin{tabular}{|c|} 
Layer \\
Diameter \\
from $(110)$, \\
$\AA$ \\
$(10), \AA$ \\
\end{tabular}} & \multirow{2}{*}{$\mid \begin{array}{c}\text { Height of } \\
\text { Orienteted } \\
\text { Layers } \\
\text { from(112) } \\
\AA \\
\AA\end{array}$} \\
\hline & $\begin{array}{l}\text { from } \\
(002), \AA\end{array}$ & $\begin{array}{l}\text { from } \\
(004), \AA\end{array}$ & & \\
\hline G.L. $1450^{\circ} \mathrm{C}$ & $56-65$ & $39-43$ & $43-\quad 47$ & * \\
\hline " 1900 & $200-300$ & $59-115$ & $160-130$ & * \\
\hline " 2300 & $150-180$ & $145-175$ & $470-1300$ & $26-29$ \\
\hline " 2750 & ? & $?$ & $\infty$ & $42-48$ \\
\hline " 3000 & ? & ? & $\infty$ & $47-54$ \\
\hline " 3200 & ? & & $\infty$ & $62-78$ \\
\hline P.C. $1450^{\circ} \mathrm{C}$ & $74-86$ & $48-56$ & $50-54$ & * \\
\hline " 1900 & $220-340$ & $150-190$ & $150-230$ & $*$ \\
\hline " 2300 & $180-240$ & $110-130$ & $280-450$ & $20-22$ \\
\hline " 2750 & $?$ & ? & $400-800$ & $29-32$ \\
\hline$" 3000$ & $?$ & ? & & $42-48$ \\
\hline$\cdot \Rightarrow 3200$ & ? & ? & $\infty$ & $42-47$ \\
\hline Anth. $1450^{\circ} \mathrm{C}$ & $18-19$ & * & $30-33$ & * \\
\hline " 1900 & $45-51$ & $*$ & $46-51$ & \\
\hline " 2300 & $110-140$ & $79-91$ & $190-250$ & $24-28$ \\
\hline " 2750 & $?$ & & $290-470$ & $24-28$ \\
\hline " 3000 & $120-150$ & $130-140$ & $\infty$ & $31-35$ \\
\hline " 3200 & $110-150$ & $120-140$ & & $33-37$ \\
\hline C.C. $1450^{\circ} \mathrm{C}$ & $14-15$ & * & $27-29$ & * \\
\hline " 1900 & $20-21$ & & $78-53$ & * \\
\hline " 2300 & $45-50$ & & $57-64$ & $*$ \\
\hline 2750 & $140-165$ & 68 - 576 & $160-230$ & $22-25$ \\
\hline 3000 & $160-220$ & $150-190$ & $260-390$ & $34-39$ \\
\hline " 3200 & $130-170$ & $130-180$ & $\infty$ & $39-47$ \\
\hline A.B. $1450^{\circ} \mathrm{C}$ & $18-19$ & * & $25-28$ & * \\
\hline " 1900 & $110-140$ & $85-100$ & $60-66$ & * \\
\hline 2300 & $145-190$ & $94-100$ & $83-100$ & * \\
\hline " $\quad 2750$ & $?$ & $?$ & $160-260$ & * \\
\hline 3000 & ? & ? & $180-340$ & $16.5-18.0$ \\
\hline " 3200 & $?$ & $?$ & $170-300$ & $19-21$ \\
\hline $\begin{array}{l}\text { Natural Flakc } \\
\text { Graphite }\end{array}$ & $?$ & ? & $\infty$ & $\mid 20-180$ \\
\hline $\begin{array}{c}\text { Graphite from } \\
\mathrm{CaC}_{2} \\
\end{array}$ & ? & $?$ & $\infty$ & $76-100$ \\
\hline$" \mathrm{Fe}_{3} \mathrm{C}$ " & ? & ? & $\infty$ & $73-95$ \\
\hline SiO" & ? & ? & $\infty$ & $80-110$ \\
\hline
\end{tabular}

* Diffractions were not exact.

? Disturbances due to orientation effect were visible.

\section{4-3. 結晶粒子の大きさ}

Table 2 に結晶粒于の大きさを示す諸数值を揭 げてある。各數值に幅と與えてあるのは試料結晶 の大きさがその範圍に分布它持つと云う意ではを く，前述の計算值の不確定を考虑しを結果による ものである. Table 1 亿揭げを值は處理溫度が高 季るに從つて總べて增大してるるが，その程度は 原料汇よつて大きな差異忐西る。

立行に重つた層群全體の高さを(002)線から計 算する己，ぞれは必必 (004)線からの值より大き

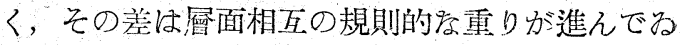


なんと考へられる試料程著しん。气れ故此の差が 層面間隔の不同に歸因するものですらら之云う說

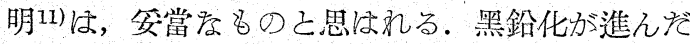
試料では，押出し法沉つて試料棒を作る己結晶 のオリエンテーション是起すととが知就てるる が，此の現象住 $(00 l)$ 線の强度基常飞强くす 当11) 己は限らず，異常に弱くする場合多る。. C. 系の試料で住强く秀る汃 G.L. 系の試料では 逆行弱くな傾向办㐫る。

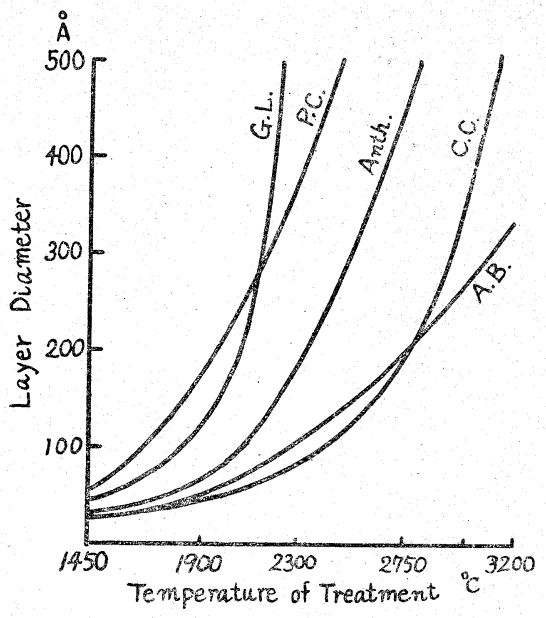

Fig. 4. Layer diameter

Fig. 4 は層面直徑の增大を示するので方。测 定值の不確定の幅の中で滑らか䎴線と孝る樣に 描いをものであるから素より正確でをんが，發達 の傾向は見るここが出來る．以上の數值から立行 に重つを層群の外形の發達は， G.L. 汃最も早く P.C., Anth., C.C., A.B. そ續くことが解る.

秩序層の厚さの變化を示す圖は第 1 報に揭げて ある. 此の值仿人造黑鉛の結晶に關する Hofmann-Wilm の模型11) を正しんとした場合に，始 めて結晶構造上の明らか意味を持つ値である 为，(101) 線办ら計算した值は常に (112) 線から の值より小さく，知ざ 1/2 しか店ん。此の差が Hofmann-Wilm の模型の正しくなんとこにるる

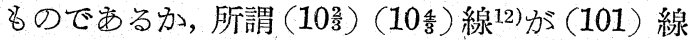
を亂すととによるるのであるかは，分明でをい*。 此の樣に「秩序層の厚さ」の物理的意味は必示 しも明らかでをんが，測定值としての之は同一試 料て就いて非常て再現性のよレ值でする. Table 1 の面間距離の值は，此の程度の測定精度では黑

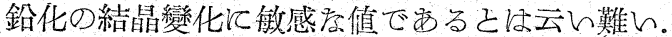
Table 2 の結晶外形飞關する數值子，存理溫度の 高い試料に就んては测定不能である. (112) 線の 牛價幅の細くをることが，何はすれ原子の三次元

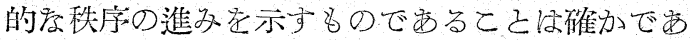
らう.

秩序礉の厚さの增加は G.L.が飛び拢けて早く, A.B. 加最子㜊ん. 加熱黑鉛化しそ試料と天然黑 鉛，及び分解黑鉛との差異も此處で明ら吕であ

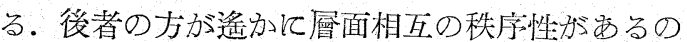
で㐫る。

(*披つを試料中に $\left(10 \frac{2}{3}\right)\left(10 \frac{4}{3}\right)$ 線等を明ら汃

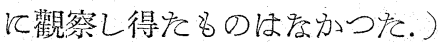

4-4. その他

層面間隔之站行層群の高さ之の間 133 に，簡單

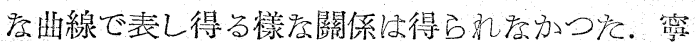
万層面間隔之層面直徑との間江稍々明らか相關 怔㐫る樣に見えた。

（110）線己(112)線乙の强度比は，信賴し得る 精度で測定するてとが出來学かつを。

\section{5. 總 括}

1）5種類の炭素原料を加熱處理した人造黑鉛 及び天然黑鉛，分解黑鉛を試料としてX線趩折を 行ん，加熱质よ当黑鉛化現象を主こして觀察し te.

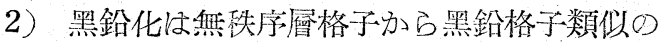
構造への連續的を變化で岗る。その際涉行層群の

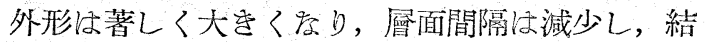
晶の比重㳊增える。

3）披つた原料を黑鉛化し易い順序に竝べると G.L., P.C., Anth., C.C., A.B. Ф順序と学る.

4） $3200^{\circ} \mathrm{C}$ 飞黑鉛化した人浩黑鉛でも，層面 相互の秩序性は天然黑鉛，分解黑鉛飞劣る。

終りに，名古屋大學杉山先生に，X線實驗に就 んて種々御指導賜つをてとをお禮雨上げます。

以上の研究實驗には，高橋登希二，川原周作， 高橋義郎，奧原滋，等汃協力几れ。

\section{文 献}

1) M. V. Laue, Z. Kristallogr. Mineral, 64, 115 (1926)

2) R. Brill, Z. Kristollogr. Mineral, 68, 387 (1928)

3）野田稻吉，炭素，2，76（1951）

4) R. E. Franklin, Acta Oryst. 4, 253 (1951)

5) B. E. Warren, Phys. Rev., 59, 693 (1941) 
6) P. Scherer, Kolloidchemie 3 ed. 387 (1920)

7) K. Biastoch \& U. Hofmann, Ang. Chem, 53, 327 (1940)

8）市瀨元吉, 炭素, 2, 41 (1951)

9) J. Blscoe \& B. E. Warren, J. App. Phys. 13, 364 (1942)

10) A. Ragoss, U. Hof̣mann \& R. Holst, Kolloid.
Z. 105, 118 (1943)

11) U. Hofmann \& D. Wilm, Ż. Elektrochem. 42, $504(1936)$

12) H. Lipson \& A. R. Stokes, Proc. Roy. Soc., A, 181, 101 (1942)

13) J.T. Randall \& H.P. Rooksby, Nature, 129, 280 (1932)

\title{
炭素製品の電氣比抵抗測定法
}

\author{
慶應義塾大學工學部＼cjkstart宗宮知行，三谷和男，斎藤正昭 \\ Measurement of Electric Specific Resistance of Carbon Products. \\ Tomoyuki Somiya, Kazuo Mitani, Masaaki Saito \\ (Faculty of Engineering, Keio-Gijuku University)
}

Simple and rapid methods of electric specific resistance measurements of carbon products are described. The principles are based upon utilising the eddy current loss in the carbon products. By using these methods, the specific resistance can be measured without any works on the carbon products.

\section{1. 緒 言}

一般に炭素製品の電氣比抵抗测定に梅，製品に 直流を流しての電壓降下法が使用さ礼て居る。金 層刷子の如く，比抵抗の小さんもの又斷面積の 大きん電極の場合等では相當量の電流を必要とす る。弦飞述べる第1の方法は高周波電源学使用し 炭素製品中に洞電流を生ぜしめて測定するもので 叻つて，此满電流により製品中に生和る損失为製 品の比抵抗己一定關係を有する事を利用したるの で㐫る。この方法は（1）测定操作の簡易を事 (2)電壓降下法等记起る電流導入の操作吕不要后 事 (3)圓又は矩形斷面積の製品で一樣を斷面積 を有する物であれば大きさの大小には無關係に测 定出來る事 (4)品質均一性の簡單を檢査が同時 江出來る點等が特徵である，第 2 の方法は直流の 代りに商用周波數の交流老使用するのであつて， 變流器を使用する事により任意の大きさの電流が 得られる便宜がある. 本法几電流表皮作用を加味 する時は交流を使用する特徵が一㲊發揮出來る。 夫等の方法に就々て順次記述する。

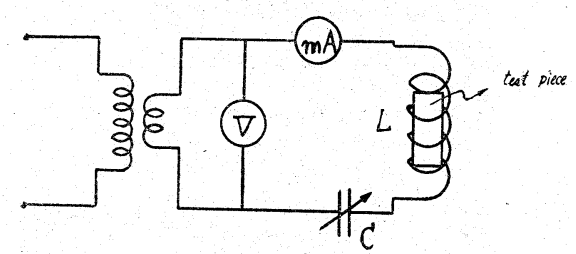

Fig.l

\section{2. 測定法 (第 1 )}

测定法行第1 圖飞示す如く, 安定發振器と粗結 合せる共振包路を使用し，線輪L中に試料を挿入 しを時，試科中に瀜電流損を生し共振包路の實效 抵抗が增加する。試料挿入前之插入後の共振回路 の電壓を一定とし，今そ礼を $V$ こす，共振包路 の抵抗を $R_{c}$, 試片捙入によつて增加しを抵抗を $R$ とする.

$$
\begin{aligned}
& I_{1}=\text { 試料拆入前の共振回路電流 } \\
& I_{2}=\text { 試料挿入後の共振回路電流 }
\end{aligned}
$$

とする時

$$
I_{1}=V / R_{c}, I_{2}=\frac{V}{R_{c}+R} \text { となる。 }
$$

